\title{
A Nihilistic Delirium to Catharsis the Fantasy for a Better World: A Historical and Literary Re-contextualization of the Musical Role of Velvet Underground
}

\section{Mahesh Hapugoda}

Department of Languages, Faculty of Social Sciences and Languages, Sabaragamuwa University of Sri Lanka, P.O. Box - 02, Belihul-Oya. hapugoda@gmail.com

\begin{abstract}
Velvet Underground (referred as Velvets from here on in this essay) is one of the most authentic, influential but least talked rock bands in the history of rock music, whose contribution is greatly forgotten in presence of the high popularity of the commercial form of rock. Started in 1966, the Velvets successfully articulated the avant-garde movement in 1950s and the European eliticism to create an independent, nihilistic and subversive form of rock which was later known as punk. Their style was the most self-expressive and pessimistic rock structure to go in between the hippie psychedelia influenced by existentialism and German expressionism; the two most influential ideological reactions which dominated the intellectual and literary tradition for decades in the post-war Europe. Without identifying with both hegemonic strands, the Velvets pertinently invented their own independent way to express the most profound and authentic feelings of their generation. They were later celebrated for their intellectual and artistic use of rock with great amount of experiments along side avant-gardism. In their poignantly arranged, de-aesthetic songs, though inspired by the use of heroin, have shown an imagination for the need of a better world. This paper will research how their self-expressive, nihilistic and notorious dreams which actually meant to get rid of the era's desperation can be literary re-articulated to vision a futuristic better world. Though this situation of nihilism and futuristic hope is paradoxical, it is the very dilemma of the era and of modernity. The visualization of Velvet's fantasy is, if psychoanalytically contextualized, in the form of a nihilistic delirium made through drugs and, resulted as, in Freudian terms, a catharsis to release the masculine libido; the sexual energy in the $I d$ and sometimes as thanatos; the death instinct: both the animal within us. Their death instinct is also illuminated by the fact that they denied the 'pleasure principle', or in other words, the entertainment aspect in rock music. In this case, they are studied here as the first rock band with taboo adult fantasies in their songs which were mainly not for kids. This discussion will also observe their deliberate and positive use of deviant social attitudes, sexual perversion, underground metropolistic and seductive urbanistic hyper -realism in their songs in fantasizing the future better world against the contemporary monotonous, de-humanized socio-
\end{abstract}


political structures. Their attempt to go beyond the political reactionism of that era towards a political radicalism, which was not the usual case in the time, will be paid attention to, while discussing their style and lyrics. Velvets' contribution to rock music will historically be restructured in the first part, and the content will be literarily evaluated through some of their renowned lyrics in the second part of this dialogue to prove the hypothesis.

Key Words: Artistic and psychedelic Rock, delirium, fantasy, catharsis, political nihilism, hyper-realism, death instinct.

\section{Methodology}

This paper will flow as literary essay by post-structurally and semantically analyzing the musical caliber of the Velvet Underground and the historical socio-cultural impact that they created in 1960s rock scene. Velvets' lyrics and themes will psychoanalytically be re-evaluated to find whether the content actually carries what they intended to have in them. They will sometimes be compared with other contemporary popular rock bands to reveal their depth, complexity and radical experimentalism which did not attract the public, who were blinded by commercial rock. This essay will elaborate both the historical importance of Velvets, in the first section, and their intelligent, classical and poetic use of lyrics in the second. Further, their historical place in rock will be extendedly discussed in comparison to the function of other rockers at the time to position Velvets at the right place. In this survey, only the most influential lyrics will be taken into account but some extremely important, musically and aesthetically significant and realistic ones will be omitted due to the space factor here. They were immensely lengthy as a result of Velvets' experimentations. Since the lyrics are commonly available online, they are not attached in the appendix but the important URLs are given sometimes. It must be mentioned here that I happened, in some occasions, to depend on online sources, as written material on rock music are extremely rare to find in Sri Lanka. That might have an impact on the strength of the evidence that I intend to prove my hypothesis with.

\section{Historical Re-contextualization}

\section{Introduction}

Rock music is a highly popular global form of art. Beyond its musicality, it is a live, energetic, vociferous and ferocious way of expressing very profound human experiences. It has been used, over its comparatively short history, to articulate important socio-political themes in the century. Rock is not only a genre of music with its subcategories such as hard rock, art rock, psychedelic, metal, heavy metal or punk, but is also treated as a movement, life style, culture and an ideology. It rose to its universal fame in the 1950s in way of 
rock ' $n$ ' roll, which is now understood and categorized as 'oldies'. The fifties rock ' $n$ ' roll did not last long, but the 60 s style is even remembered today. Sometimes rock is treated as folklore and a belief system in which people identify themselves. It can rightly be defined as the key to the most explosive popular culture in the $60 \mathrm{~s}$ and 70 s until overtaken by pop and disco in the 80 s. However, the global rock fan base is innumerable and the impact it had on the Western civilization is convincing and bewildering.

Rock in the sixties has been generally understood as a form of music which represented an experimental, self-expressive, and rebellious and an improvised form of alternative music genre against the popular, easy-listening pop ditties of the 1940 and 50s. It also brought out the political protest and reaction (as in case of Dylan) and the explosive generational anger (The Rolling Stones would be an ideal example) of the post-war Europe; the fear and angst of the Cold war and the Vietnam war and of the ones who wanted an alternative cultural value system in opposition to that of the Puritans; and catered those who wanted to change the world and who were tired of three-minute ditties of pop music which had been crafted for decades. Rock music of that age is understood as a form with space for psychological narrations, anti-establishment satire, political denunciation, drugs, sex and death (Scaruffi, 2003). Historically speaking, rock music was as African-American development which has its roots in African blues music. According Townshed, 'if every society, after all, has its indigenous music, which serves as entertainment, accompaniment to ritual and ceremony, bonding force, story teller, preserver of history; the rock, certainly, is modern American folk music' (Townshed, 1999). But rock travels beyond the destination of a ritualistic entertainment and cultural adhesive status, since it captures the very soul of the American civilization from 1950s to 1970 s and even beyond.

Under this phenomenon, the emergence of Velvet Underground ${ }^{1}$ looks alarmingly controversial, since the innovations and experiments that they brought about to the rock arena have never been tried before. Velvet Underground was the most important and influential rock band in 1960s, which made a great impact on the contemporary rock arena and changed its pathway of rock for another couple of decades. Many rock critics and artists recognize that Velvets are the most artistic, innovative and experimental band of all time in the history of rock (Scaruffi, 2003), though they were not popular as the other contemporary rock giants such as The Beatles or The Rolling Stones, The Who or perhaps The Kinks. The world knew them simply because of Andy Warhol's multimedia show 'The Exploding the Plastic Inevitable'. The main reason for their less popularity was due to their advanced, ahead of time musicality, experimentation and the realistic social criticism which the popular bands were afraid to touch in fear of loosing popularity. By being 
realistic and critical about the society and individuals Velvets did not become 'popular teen idols' such as 'The Beatles' but they became true to the spirit of rock music. In doing so, they identified themselves with the discarded, marginalized and anti-establishmental nature of the urban youths in that era. Nevertheless, we should not forget the fact that both Lou Reed and John Cale, the leading members of the band, were classically educated youths who were aware of the avant-garde movement, who had obviously nothing to borrow from popular music.

Even though they were nihilistic due to era's frustration and their use of heavy drugs, the meanings they brought out can be articulated deeply within the peripheries of a revolutionary movement that may rise one day. The desperate urbanism and its evils have never been captured more vividly than the way Velvets have; and the symbolic value that they bear as an urban group of youths who sought something alternative to the dogmatic, hegemonic and bourgeoisie values that were spreading in every social stratum should academically and politically be evaluated to understand the dark, urban underworld better. It could also have been even more valuable, if Velvets were studied and their themes were articulated by a revolutionary political movement to enlighten the public mass. Since most of the rock bands were either silent about the intolerable social unjust at that time or were not directly representing the agony of the youths, Velvets become 'an ahead of time revolutionaries' in their own way, in relation to their true outspoken nature and by becoming true to the spirit of rock. This literary survey will observe how their nihilistic deliriums resulted from heavy drugs such as heroin; emerge as futuristic hope from the fog of era's desperation. It will also investigate how their songs work as an eye-opener to change the world and as a form of de-aesthetized poetry to catharsise their own ego and character, in addition. It is a gratitude for them to presume that they did not abandon the contemporary rebellious generation who dreamt for a better future. Such contextualization is academically urged to appreciate their historical and literary role which has been under-determined, within the commercially over-determined rock phenomenon in the consumer stage of capitalism.

\section{Defining Rock Music and Its History in Brief:}

Rock music started with slavery. The history books will bear no better witness to offer the truthful background to rock without tracing back to the uprooting of thousands of African from their native lands and cultures to transplant them in what is known as 'the new world'. The music that the Africans brought from their homelands was the only vehicle of the expression of the trauma of thrashing a fellow human group into unending servitude, the core of the modern Western civilization. This human agony, as sited by Townshed, is; 
'families were split apart, slaves from different tribes were thrown together on the same plantations, and, of course, these reluctant visitors were chained, whipped, imprisoned, and compelled to perform excruciating hard labor for barely subsistence nourishment. Keep in mind that these conditions continued, on this continent, for well over a century, until less than 150 years ago' (Townshed, 1999).

From this servitude situation the blacks could never recover. They have resided on to drugs, crimes and violence until today. They were never paid a psychological compensation for the recovery from the loss of the traditional past to set themselves in the secular modernity (Harbamas, 2003). At the same time, they wanted something to express their unending suffering which took place in the form of a break of a civilization. They did not choose the 'soft' blues or jazz as the right form of catharsis of the trauma. The Afro- American hybrid of rock ' $n$ ' roll was the option. It is wrong to say that rock ' $n$ ' roll was entirely black but, without slaves, rock ' $n$ ' roll was never possible. Whites too realized that this is a strong form of spiritual expression and entertainment and, started to borrow this 'devilish music' which actually came from the burning souls from the alienated blacks. For the desperate souls of the white youths who were also marginalized as the outcasts of capitalism (Bauman, $2004 \& 2005)$, rock had something to offer. This is how these two groups met to formulate the most expressive, ever cross-cultural product in the American soil.

With the radio, rock continued to produce some galvanizing and most remembered music in this century. It was during the 50s that rock was taken to the popular culture to entertain public. With the record industries, the black form of music was exploited and eventually transmitted to the white teenagers who had money to buy those records and wanted something exciting. But originally these ethnic groups were racially divided. The meeting point of these segregated communities was the commoditized and commercialized rock ' $n$ ' roll. Blacks were singing something that the white teenagers could relate to. It was all about the prohibited subjects such as adolescent love or taboos which had a great appeal on the youths who still were under the influence of the remnants of Puritan adults. The contemporary county or blues and their childish rhymes could not produce something substantial to address the tormented souls of the white youth who were equally alienated in the industrial capitalism. This binary oppositional meeting point is the historical conjuncture of the popular form of rock ' $\mathrm{n}$ ' roll that we experience today.

Technically, rock music is generally understood as a genre of popular music employing electric guitar, bass and drums sometimes with a strong back beat. It is also defined on the basis of the availability of a strong back beat, since rock music does have such exclusiveness. However, the difference between 
British and American is surprisingly huge and, as a result, the Encyclopedia Britannica Online ${ }^{2}$ suggests that defining rock is problematic since least because the term has different resonance in its British and American usages (the latter is broader in compass). Apart from this continental difference, rock genre has been divided to many sub-genres over the last fifty years followed by many stylish, thematic and structural varieties.

The Collins Cobuild English Dictionary, based on a vast database of British usage, suggests that 'rock is a kind of music with simple tunes and a very strong beat that is played and sung, usually loudly, by a small group of people with electric guitars and drums,' and further it suggests that 'rock and roll is a type of pop music originating with a blend of rhythm and blues and country and western' ${ }^{3}$ but there are so many other contexts that encompass these technical descriptions which might dig out more historical and political factors to give us a more lively background. According to the Wikipedia online,

'Rock music is a form of popular music with a prominent vocal melody accompanied by guitar, drums and bass. Many styles of rock music also use keyboard instruments such as organ, piano, mellotron, and synthesizers. Other instruments sometimes utilized in rock include harmonica, violin, flute, banjo, melodic, and timpani. Also less common stringed instruments such as mandolin and sitar are used. Rock music usually has a strong back beat, and often revolves around the guitar, either solid electric, hollow electric or acoustic'4.

Rock music was the dominant form of popular music in the $1950 \mathrm{~s}, 60 \mathrm{~s}$ and $70 \mathrm{~s}$ but its grandeur diminished after the introduction of other forms of music such as pop, disco, hip hops and electronic in the late 70s and 80s and afterwards. In 1950, it was rock ' $\mathrm{n}$ ' roll which shocked the world with The Beatles. With them and many other great artists, rock music became the global form of music towards the end of 1970s and may be a bit afterwards. It is important to remember that before The Beatles, there were many popular musicians whose works significantly contributed to rock music in many different ways. For instance, Bo Diddley's Mona (1957) and I am a Man (1955), Chuck Berry's Sweet Little Sixteen (1958), Roll over Beethoven (1956) and Johnny be Goode (1958) made rock history remembered up to date. Both Diddley and Berry not only electrified millions of youths at that time (Scaruffi 2003) but showed what guitar can do in rock music. After that, there was a pianist called Little Richard who invented decadence rock, a sub-genre with which historically important hits such as Tutti Futti (1955), Lucille (1957) and Good Golly Miss Molly (1958) were made. Richard introduced a hysteric pace to rock music which was inherited by many later artists. Apart from Richard, the two white musicians Jerry Lee Lewis and historic Elvis Presley too must be mentioned 
here. However, it was Buddy Holly who brought a school uniform plus a childlike appearance to rock, which was copied by The Beatles and was extremely popular among teens.

The Beatles, with their extreme commercial success, changed the appearance of rock music forever. Many critics point out that because of the over-success The Beatles did not grasp the true spirit of rock; the way many other later rock bands and artists did. However, the giant bands such as The Rolling Stones, The Who, The Kinks, dominated the rock arena in the 60s and in 70s but The Jefferson Airplane, The Grateful Dead too were extremely popular with their identification with contemporary political trends. Their approach to rock was, however, different from that of The Beatles or at least they did not look like them. Many rockers during that time were either hippies or acquired most of their values from the political trends such as peace movements, sexual revolutionaries or left wing. Many were heavily addicted to psychedelic drugs. Their lives were influenced by post-war ideologies such as existentialism or expressionism. It is noteworthy that the hippie movement was also based on the existential way of thinking and is considered one of the most powerful socio-political movement in Europe in general and in the States in particular. Hippies were followed by the punk tradition which was also equally influential in West.

The Velvets were neither hippie nor established musicians, but were elitist musicians who were aware of the avant-garde movement, even though the hippie was the political and cultural trend at the time. Velvet established a style in the rock music, which was overwhelmingly intelligent and antimainstream, and was structurally different from the three minute ditties of The Beatles who dominated the scene. It is important to mention here, as a result of the excessive commercial success and popularity of The Beatles, in 1960s specially, all other talented bands which were ideologically and musically different from them were covered by their huge shadow. They could not represent the true historical spirit of rock because they were manipulated towards a commercial success by the producers who wanted nothing but money. What is the exclusiveness in rock? The specialness is in its origin.

"We must also remember here that rock music is different from other music forms such as blues, R \& B or Jazz, simply because rock is meant to represent the alienation and the anxiety of the ethnically disintegrated blacks from their original homes due to slavery during the colonization....

Rock ' $\mathrm{n}$ ' roll can be traced in a direct line to an utterly unnatural phenomenon; the forced uprooting of tens of thousands of Africans 
from their native lands and cultures, and their transplantation. To a new world as different from what they had known as black is different from white" (Townshed 1999).

This shows that rock ' $n$ ' roll is a result of a historical social evolution of suppressed, alleviated and thrashed African blacks who make a window to history. They belong to the very socio-cultural fabric of America. In this regard, the above critic further mentions that,

"To understand rock ' $n$ ' roll, therefore, we must understand what slavery was, and where it left the sons and daughters of Africans who knew nothing of the European roots of American culture. For slavery provides the perfect rationale, the perfect explanation why rock ' $n$ ' roll should stand apart from other musical forms, as a cultural revolution unto itself. Every society, after all, has its indigenous music, which serves as entertainment, accompaniment to ritual and ceremony, bonding force, story teller, and preserver of history. Rock ' $\mathrm{n}$ ' roll, certainly, is modern American folk music in these respects, successor to Stephen Foster and Cole Parter. But that is only a minor facet of rock ' $n$ ' roll's place in American, indeed in world society since 1955, and the larger element of rock's influence reach for beyond the traditional cultural adhesive status of other folk music. Solidity this claim, and to explain it, we can point directly to slavery, which forcibly mixed the radically different element of two cultures in a boiling cauldron (rather than melting pot), bringing to white, rural, agrarian American a series of vocal and rhythmic traditions that originated on the other side of the planet in Africa, and adding an important spiritual, melancholy, almost fatalistic sensibility that grew up by itself in the slaves' imprisoned souls" (Townshed, 1999).

So, this gives evidence to the fact that the origin of rock music is tied with a traumatic history of an African-American hybrid generation who used music to transcend earthly pain for a while. The Blues which was also of the same origin was used to relieve the pain, the sadness, toil and loss cause, through repetitive rhythms and chards and lyrical phrases. But the gentle nature of Blues which served as a spiritual function was insufficient to express the true soul of the oppressed, deprived and purposeless black slaves. It is interesting to note here that after a century, the whites borrowed rock ' $n$ ' roll to express the cataclysmic horrification, generational anger and genocidical destruction of a generation, which had tremendous psychological trauma after the First and Second World Wars and the Vietnam War. It was also re-articulated in a very successful commercial phenomenon in the form of The Beatles (including several other 'teen-idol' popular celebrities such as Elvis Presley 
and Buddy Holly), which were an artificial formulation in the empty market space. The touchy and rebellious form of music was pumped out to make soft easy listening stuff for the middle class kids and this new form was harmless to the established form of political and cultural bodies. The new 'sellable rock' was de-politicized, de-bourgeois, anesthetized 'sleeping tables' for the lazy middle class in the post-industrial Europe. In other words, rock became to function as an 'empty signifier' without representing or bearing any material truth or a reality with its proliferated signs.

But by surpassing this huge commercial success and popularity, few contemporary rock bands who were either less popular or not at all came forward to discover the true spirit of rock to re-narrate the uncompromisingly restless minds of the youths, who were alienated by capitalism and who wanted to challenge the values of the adults, and who were revolutionary against the establishments which restricted socio-cultural freedom. Such inspirational bands were namely the Rolling Stones, The Who, The Kinks and the VelvetUunderground and later Pink Floyd, Grateful Dead and the Jefferson Airplane. All these bands were either the representatives of the contemporary socio-cultural and political trends such as the hippie movement, anti-war movement, students' protests or generational struggles, or the spokes persons and the participators of those trends. With these bands, rock 'n' roll far exceeded any political or cultural movement that had preceded it. Music became the terminal stage of an anelastic process; from social alienation to musical alienation to musical revolution to social revolution. With the rock music in 1950s 60s and 70s, music became not only a universal language and more than entertainment, but also a revolutionary tool for the youth of the USA in particular, and in Europe in general.

With its anti-establishment and anti-bourgeois nature, rock remained a 'clandestine' and 'underground' genre in the beginning, but in 1955 the establishment applied the capitalistic rules of mass marketing to this new product, and sanctioned its existence. Eventually, the above mentioned bands, with a great dedication, re-invented rock to sound something different from the older and traditional tone of popular music. This new rock ' $n$ ' roll denied the sentimental, the tragic and the comic tones of popular music and allowed the erotic, violent and sarcastic form, which was truly the teenager's view of the world at that time. Scaruffi further mentions about the atmosphere of the youths when this new form of self-expressive rock came to effect.

'Puritan were right, when they claimed that rockers (by appropriating the convulsions of stripper, the sensuality of perverts, and the savagery of blacks) were inciting male teenagers to became prostitutes. It was their way to next a generation's feeling of independence' (Scaruffi, 2003). 
With the fast growing capitalism and the creation of an alienated, underground,' dark' segment of the individuals who were not absorbed by the establishments of the main stream was an essential by product. To understand that phenomena better, we must turn to what was happening in the industrial metropolitans.

'Accumulation of wealth at one pole is, therefore, at the same time accumulation of misery, agony of toil, slavery, ignorance, brutality, mental degradation, at the opposite pole' (Marx and Engels, 2000).

The above Marxian statement is a clear guidance to understand the misery of the urban, down trodden class, who was at the receiving end of the disadvantageous economic polarization, and who were 'unaccepted' by the rich. The financial frustration of the youths was further set back by the postwar fear and angst, the Vietnam War, and the Cold-war nuclear holocaust. Those who promised a future better world were no more reliable whether left or right, and this new frustration generated made a fresh ideological turmoil to challenge the older generation and their values and politics. The above angst and the different ideology yielded a great reason for psychedelic music, a music that reflected the spirit of the time, that experimented with studio sound and that embodied the psychological frustration of the youths. This new trend was further described by Scaruffi as follows;

'The synthesis of 1966 was fueled by hallucinogens, as if drugs were the natural meeting point of the bard, the punk and the sound sculptor. Most likely, it was a mere coincidence: drugs just happened to represent the unifying call of arms of that generation. It might as well have been something else. Drugs were conveniently available and stood for the opposite of what the hated establishments stood for War, bourgeois life, discipline, greed, organized religion, old fashioned moral values' (Scaruffi, 2003).

So, the new music style in rock in mid 1960s to entire 1970s was the psychedelic; opposite to mainstream commercial music of three-minute, termed as punk or acid 'jam' whose ingredients were of a much more complex recipe.

The first representatives of this free, loosely constructed style were Velvets to start with and then followed by Jefferson Airplane, the Grateful Dead and the Pink Floyd. Their innovations were no longer related to rhythm and blues or country music but to jazz. This new way of style actually led to create a very strong social movement and a counter- culture which was secondary only to the civil right movement and to the hippies in its participation and existence.

Of these entire line of rock psychedelic bands, not forgetting the other two hard 
rock revolutionaries such as the 'Rolling Stones' and The Who, the Velvets are the first to consider rock as a creative art, not as commercial product to sell in the market. Their prime purpose was to communicate with their environment, to transmit emotions and to express uneasiness. They are also the first and foremost example of creative freedom: the band wrote what it felt like, arranged it as it pleased, and played it how it wanted, while most other bands and musicians supplied what the producers and the audience demanded in fear of losing commercial success. On the other hand, since Lou Reed was a student of English Literature and was a friend of Delmore Schwortz at Syracuse University, who was a poet, Velvets' lyrics were very much poetic; and since John Cale was a classically educated avant-garde musician, they were able to produce masterpieces which could stand with any form of music at any level. It is this poetic quality of their songs which inspired me to write this literacy essay. At the same time, it is noteworthy that their innovative style and artistic adherence to explore a new world and a new music which have not been attempted by other rock bands was another motivation to research on the Velvets. The other intention was to search how poetry can be articulated in lyrics to such a creative extent that a community can be awakened to find out their ignorance, blindness about the truths that are at arms length. The Velvets showed who and where people were at a time when individuals were forced to forget their identities.

\section{Placing the Velvet Underground in the 60s and 70s Rock Arena}

The rock music after The Beatles, adjusted itself according to the demand of the mass form of art, which was highly commercialized in the hands of few entertainment companies. The cynicism and the pessimism of the generation, which was retarded by the Vietnam War, fear of the Cold War, human avalanche and catastrophe of the post World Wars were not properly understood by any rock artist other than Velvets.

Nowadays, Velvets are considered as one of the most important rock groups in the history of rock, because of their enormous impact on it (Harvard, 2007). But still the mainstream radio stations remain Velvet free. Enough attention is not paid for their laborious effort to improve modern rock and to the profound experimentations that brought a new inspiration to the contemporary rock, which had never been tried before at any length. It is difficult to define the function of the Velvets since they did not authentically belong to any of the rock categories in the contemporary scene. It is a strange and excellent form of combination of two great musicians namely, John Cale and Lou Reed. As mentioned above, Cale was an avant-classist and Reed was a great poet and a lyrist. But the Velvets cannot simply be measured through the magical mix of Cale's avant-gardism and Reed's poetic lyricism; but they must be evaluated through their truthfulness to the essence of rock music. The easiest 
way to define them is to look at their strangeness and deviance. They brought heroin, orgies, methamphetamine, bondage and discipline, physical and emotional submission, violence, transgender, transvestites, transsexuals and street-wise deviance (Ibid) to the rock arena at a time those elements were not pronouncedly talked in popular music. As Cale once rightly mentioned in 1986, when the Velvets were inducted to the Rock and Roll Hall of Fame, 'Sales are not the be-all and end-all. Inspiration and artistic freedom are the cornerstones of rock and roll'. They remained the most influential but most commercially unsuccessful band in the history of rock. If one views pop music as a disposable commodity whose value is measured through sales units, the case of Velvet is especially problematic. So, the populist and commercial standards that may apply to measure the success of the rock bands will not be applicable to Velvets. Therefore, new artistic and music standards must be reinvented in relation to the Velvets, because they were far away from the mass art form of the time.

When The Beatles were identified in their popular over-deterministic Beatlemanic atmosphere and The Rolling Stones, The Who with rebellion outcasts and generational anger, the Jefferson Airplane or Grateful Dead with Hippies, the Velvets just hanged around the streets with heroin without sticking any such identities. However, the way that the Velvets have been defined by various music critics will be useful to contextualize them in the scope of this dialogue. Those definitions will explore their historical role as a rock band and how they can retroactively be seen today. However, as a common characteristic and a salient feature, all agree on one point i.e. Velvets' love to be experimental, introvert, urbanistic and the nihilistic. According to Patti Smith;

"They (Velvets) were the stark, elusive balloon that burst upon an inflated scene, injecting that scene with radiance that connected poetry, the avant-garde and rock and roll. They were a band of opposites, shooting freely from pole to pole, without apology, with dissonant beauty, tramping the flower of peacemaker, treading the blond depth, black in the white world, and white in the black world. They opened wounds worth opening with brutal innocence, without apology, cutting across the grain, gritty, urbanic. And in the search for the kingdom, for laughter, for salvation, they explored the darkest area of psyche" (Zak, 1997).

Velvets were, however, the by product of the true spirit of rock and representatives of urban hooliganism and scavengerism. The bourgeois academia will be reluctant to study them, because their living standards will have a disturbing and traumatic impact on them. They are most authentic 
representatives of the reason's modern world and its barbarianism. They were not only a symbolic mirror to reflect the world we live in but a traumatic source to majestically saturnine the bourgeois kiddy music and the life style of the generation.

"The Velvets were less a source than a symbol and mirror. For those whom the band meant, it represented confirmation of a deeply held, yet perhaps unarticulated belief in rock itself: that this music so bound up with the working of industrial capital, pimply teenage fantasies, and absurd celebrity poseurs could yet be a revolution of truth, a way of knowledge and understanding, a way of getting through. Their fans believed in rock and roll with all their hearts; or at least wanted to. They were waiting, perhaps consciously, for a band that would embody and reflect upon them the light of their own faith. And whether they had any idea what they would mean, they recognized when they heard it" (Ibid).

When the commercialization of everything including music was the motto of consumer capitalism, the Velvets went on experimenting with different forms of rock music. The experiments were highly advanced in comparison to the Beatlemania and other superficial stuff. Therefore, M.C. Kostek mentioned once, "The Velvets existed to tell not to sell" (Ibid). Selling the realities that the contemporary youths were undergoing due to the great de-humanization in the name of various wars, Cold-war fear and pauperization and marginalization was not something that the Velvets were interested in. They rather choose to live with it. Since they too actually belonged to the social segment that many other youths did, they could authentically sing what others could not.

"The Velvets operated in the ragged seam between 'high' and 'low' art that opened up in the 1960s and has grown increasingly irritated (to some) and fascinating (to others) ever since" (Ibid).

As they did not get caught by the commercial signs generated through the capitalists' market orientations and profit motivations, they commercially failed to lift themselves to the big rock arena at that time but could produce the best form of artistic rock music to express the deepest psychological traumas and anxieties. As an obvious result, "their records were utter failures as commodities but became extremely successful as artworks" (Ibid). In this case, their music definitely goes beyond the political expressionism and reaction of the The Who and The Rolling Stones, the most expressive of the time. They were able to bring the most profound aspects of the psyche of the youths due to their open, cathartic and outspoken experimentalism, which grasp not only the anger of the generation, but also the deprivation and hopelessness consumed 
by the use of drugs of which Velvets were a part. As Charles Oliver observes;

'Theirs was the dim world of drugs and sexual perversion, of heroin addiction and the desperate loss of hope that goes with it. Their concern was with death and violence... Oozing evil and lubricity, they made every other group look like kid stuff, and they made a lot of people nervous... There is no word for their sound but sometimes it seems as if a presence has taken it over, perhaps even His Satanic Majesty himself. You can easily imagine someone performing black masses with the Velvet Underground's albums. Not for the kiddies' (Roxon, 1969).

The Velvets did not belong to the popular world of flowers and peace of the hippies and of the existentialists but to a rather dark and an underground world, which is the true demonic face of capitalism. They were essentially nihilistic since they had nothing to hope for and to achieve, but they had one thing to say i.e. this is not the right place to dream for. Their world view was made through the narcissistic and sadomasochistic fantasies of urbanisms. "Their world view was dark and nihilistic at a time when everyone else was singing about peace and flowers" (Ibid). They were highly sensitive to the realities of their time but not excessively vociferous about the sufferings that can easily be commercialized in turn. Silently, with an excessive caliber in imagination, even though with great commercial failures and a small fan base, the Velvets produced the most aesthetic rock of the time. 'Recording mere four studio albums and one live album in the late-'60s, the group established an aesthetic so extreme, alien and ahead of its time that it has taken three decades for the world to catch up ${ }^{5}$. The above introduction was made to be written, since even most careful rock fans were unaware that a band called the Velvets ever existed in the world.

Before the formation of the Velvets, both John Cale and Lou Reed played under different names such as the 'The Warlock', The 'Primitives' and 'The Falling Spikes' in galleries and at poetry readings around lower Manhattan. By the time of this meeting they both were academically trained musicians; Cale as a violist and Reed as pianist. Cale was engaged in avant-garde experimentations and Reed was writing poems about down-and-out street life (Scaruffi, 2003), and he had been working as a house song writer.

Their academic background helped them to become extremely capable song writers of the entire history of rock music under whatever standards it may be such as classic rock, blues or punk. As Scaruffi mentions;

"It was difficult to find a precedent for the Velvet Underground's music, because these barbarians were educated to the classical lieder 
and to LaMonte Young's minimalism, while they borrowed very little from rock'n'roll and pop music" (Ibid).

Actually, when their music and the themes are concerned, any one who is sensitive towards 60 s' rock can believe how true the above statement and how advanced their music is, when compared to what most of the popular rock bands offered to their audience at that time, including The Beatles (Scaruffi, 2003).

\section{Avant-garde Modernism and the Velvets}

The only difference that Velvets makes in them from rest of the contemporary rock bands is their awareness in the Avant-garde movement. In the modern world, what capitalism was experiencing, apart from the crisis of over accumulation, from the beginning of the $19^{\text {th }}$ Century was the time-space compression or, in other words, the annihilation of space by time. The result was the Imperialistic expansionism of capitalism and radical restructuring of social relations in every part of the world where capitalism stepped in. According to Marx,

Constant revolutionizing of production, uninterrupted disturbance of all social relations, everlasting uncertainty and agitation, distinguish the bourgeois epoch from all earlier times. All fixed, fast-frozen relationships, with their train of venerable ideas and opinions, are swept away, all new-formed ones become obsolete before they can ossify. All that is solid melts into air, all that is holy is profaned, and men at last are forced to face with sober sense the real conditions of their lives and their relations with their fellow men (Marx and Engels 2000).

So, the aesthetic modernism is actually a cultural reaction to the modernity itself. It reacted against the tension that was created by high capitalism by disturbing the old social order and relationships. Modernists' reactionism was oriented towards the psychological shock and jolt of the alienated souls who were caught in the industrial capitalism. It was a nostalgic withdrawal towards the myth of the organic community that was lost. For the men who were spilt and schizophrenic, the imaginary past was a safe retreat. In a modernist's sense, this self-protective reaction resided in what is called 'high culture'. In case of T.S. Eliot who is a paradigm in the time, the high aestheticism and the thickness in the textures that were employed in his writings were understood by the bourgeois few. Same applies to Joyce. The antagonistic reaction by them was to re-organize the scattered fragments to make a meaningful, organic whole. Their tradition symbolizes modernism's problematic relationship to the high-cultural tradition. The modernists' entire 
aesthetic endeavor rests on their production of disruptive semiotic texts which carried clashing discourses to signify a demand for a revolutionary world order immediately to be restored. However, the revolutionary avant-garde meant a radical breakdown of the barrier of social life and art, rejection of tradition and questioning the commodified social relations. Apart from that, the naked results of modernism were militarism and Fascism which produced genocide and holocaust; both were historical traumas in the human civilization (Sartre, 2002). The modernists' reaction characterized this very paradox of modernity which actually promised prosperity.

It is those modernist eliticism and reactionary aspects that were shared by Velvets. They were not hippies but were aware of this avant-garde reactionary intellectual tradition. It is through this tradition that they become experimental and independent and different from rest of the rock artists at the time. Their classical academic education immensely helped them to mark this difference. According to Scaruffi, 'their true goal was to provide a documentary of the decadent, disaffected, cynical mood that was spreading among the intelligentsia' (Scaruffi, 2003). They did this without betraying the militant and barbaric spirit of rock by reducing it to the isolated high culture phenomena. They created form of music which truly grasped the dark fresco of modern mankind.

Their poetry was not to please the academic intelligentsia but portray much darker and fathomless agony of the generation. Even though they were great poets of the metropolis, Velvets never used that for a pleasing effect. "Their poetry is a continuous reference to the degradation of modern life, to the alienation of the city, to the existential desperation of chronic loneliness, to the moral and physical violence shared by an entire population of modern "losers" (Ibid).

\section{Heroin and Death Drive}

They were heavy users of heroin against the typical LSD tradition of the hippy psychedelic. Heroin is more sinister and delirium. They lived in a dim world of drug and sexual perversion. Here, the death drive is discussed in relation to their reluctance to engage in producing pessimistic and pleasure oriented music. As Slavoj Zizek mentions, the 'death drive', according to structuralism, is understood with symbolic order 'in so far as it follows its own laws beyond the Imaginary experience of the subject, that is to say, 'beyond the pleasure principle' (Zizek, 2006a). Velvets lived in a time where the symbolic order has been disturbed or annihilated by the seductive capitalism. Here the death also refers to the symbolic death resulted from the cognitive break or disruption of the socio-psychological automation which maintained the subject's equilibrium. The commercial capitalism completely annihilated the symbolic universe or the corporal reality of the societies by making its subjects perverts 
or psychologically sick in one way or the other. The Velvets became the true representative of the death instinct and the psychological perversion of the generation at a time of loss.

The music that they produced did not intended to be entertaining but expressive. The denial of the commoditization is also part of their denial to be identified with the main stream rock which targeted to be sold for an entertaining crowd who made fun out of music. So, in short, Velvets rejected to be identified with the over-determined 'pleasure principle' which was at work in commercial popular rock. They instead remained an off beaten track, experimental art rock band which articulated even lengthy tribal form of music to express the unending agony of the time for hours for the little crowd who listened to them. Their superb songs such as Femme Fatale, All Tomorrow's Parties and Black Angel's Death Song, together with the percussive boogie Waiting for My Man resulted from the hard boiled souls that were withdrawing from the dream of prosperity of the modern capitalism to the underground corners of the street. And the chaos of Heroin is their Dantesque lament for the desolation of modern life. The use of tribal music in European Son, and the Indian classic music stained in Venus in Furs are best examples to show the experimentation to mark a clear cut deviation from rock 'n' roll and pop. Through them, Velvets explored their male libido which was directing towards a dark death through fetish sexual fantasies. The songs are, in a way, cathartic release of the dream for a better world.

The death instinct and the denial of pleasure as mentioned above did not appropriate the commercial form of music. No one wanted to listen to their tormenting lamentations in the form of music which generated a trauma. As a consequence, they were also among the first bands to show total disregard for the charts. The aim of their music was to transmit emotions, to express uneasiness, to communicate within their environment. The motto of the postindustrial entertainment culture which demands 'pleasure' with no care for the limitations imposed by reality (Zizek, 2008) is not applicable to Velvets because, in opposition to pleasure, they were seeking death instead. If that aspect is taken together with their urge to experiment and the limitless independence which was not restricted by commercial motives, they become the most truthful modernists of the era with an anti-bourgeois existence. But the nihilism and hyper-realism are marks of the kind of modernity afterwards.

\section{Velvets' True Legacy, Identity and Supremacy in Rock}

They neither lived in nor got blinded by the glazing neon lights of the profit oriented consumer capital unlike The Beatles. The velvets stuck by their own standards and did nothing or little to share with the contemporary existentialists, hippies and the San Francisco rockers. Their identity is unique 
as the representatives of the classical avant-gardism, intelligentsia and more sinister heroin culture. They were not the LSDs which are utopistic and dreamy. They introduced the most pessimistic standards to rock music. That pessimistic and subversive nihilism led to establish what is known as 'punk rock'; the style which dominated in the 70s. To accurately mention what their legacy was in the history of rock, it is suitable to quote what Brian Eno has once famously said as, "that not many people bought the Velvet's albums when they were originally released, but everyone who did formed a band' ${ }^{6}$. After bravely jousting the twin enemies of indifference and open hostility in its lifetime, the Velvets has gradually been embraced as one of the best and most important bands in rock history. The legacy of rock bears a very high place for Velvets, since their practice of music made a foundation to a new tradition in the Western civilization in mid 1970s as what is called the "punk subculture'7. Velvets are the first punk rock band in the history of rock music.

Secondly, it is important to study Velvet and rock music which was the sole weapon that the urban youths had to show their political protest and antagonism towards the establishments. According to Terry Eagleton, by the end of the Velvet's time (mid 1970s); 'the Western history was at a turn. Although I could not have known it at that time, an era of political radicalism was just about to slide into one of political reaction' (Eagleton, 2002). It can be believed that Velvets' music, as in case of Dylan, goes beyond the boundaries of resistance and reactionism. Their musical 'sign' was to create the reality in which they were living into the signifying language of music. As Scaruffi mentions, 'the metropolis was reduced to an endless pulsing noise, daily life was reduced to an unconscious delirium, and everything, both public and private, was clouded in pure, Freudian libido' (Scaruffi, 2003). The chaotic and de-humanistic urbanism was made a hyper-reality in the grip of drugs and perversion. The seductive and terrific nature of the urbanism has never been so vividly and impressively portrayed in rock music any other band in the contemporary times others than Velvets.

As mentioned earlier, their identity is further illuminated by the fact that their purpose goes beyond just entertaining of the public. This is also why they were not popular in the arena. The band sought not just to entertain and react, but to challenge, to prove that rock ' $n$ ' roll could be a dangerous weapon that can direct against the bourgeoisie. In that, they used their classical music background to articulate the protest. In this endeavor, they gravitated not towards French existentialism but towards Andy Warhol — who brought Austrian actress/model/chanteuse Nico into the fold - and became fixtures in Warhol's multimedia organization, the Factory, and in the Village bohemian art scene. That is one historical example in which populism and political radicalism intermixed to produce something that can have an impact on mass. 
If The Doors are considered to be the most creative band in the history of rock, the Velvets become only second to them, but as long as the experiments are considered, they were the best without ant doubt. In reducing rock ' $n$ ' roll to its harshest essentials, the new wave took Lou Reed's aesthete-punk conceit to a place he never intended. For the Velvets the aesthete-punk stance was a way of surviving in a world that was out to kill you; the point was not to glorify the punk, or even to curse the world, but to be honest about the strategies people adopt in a desperate situation. The Velvets were not nihilists but moralists. In their universe nihilism regularly appears as a vivid but unholy temptation, love and its attendant vulnerability as scary and poignant imperatives. Though Lou Reed rejected optimism, he was enough of his time to crave transcendence. And finally, quoting from Ellen Willis, "Rock And Roll" makes explicit, the Velvets' use of a mass art form was a metaphor for transcendence, for connection, for resistance to solipsism and despair (Marcus, 1979).

Theirs were not songs because they did not sing but rather cheerlessly reported an intolerable reality through soundtracks. Those 'songs' cannot, under any standards, be placed or compared with the type that were popularized and commonly heard at the time or even today. However, their supremacy in rock music is remembered due to their denial to identify with commercial form of rock, denial of the pleasure orientation and drive towards an unconscious delirium instead of a the sweet dreams that The Beatles form of ditties were promoting. But their nihilistic dreams are never deprived of signifying the necessity to change the world for a better place. Their lyrics are studied from now on to prove this hypothesis.

\section{Literary Appreciation of Velvet's Lyrics}

Velvet Underground has released four albums during their short journey. The first was named The Velvet Underground and Nico, recorded in the Spring of 1966 performed together with German actress and singer Nico (Christa Paffgen $)^{8}$. That is perhaps the best masterpiece which sustained their mark in the history. Next was the White Light White Heat which was released without Nico who abandoned the band after several failed concerts in empty theaters. But the physical vacuum that her absence created was filled by Cale's experimental new innovations and Reed's self-expressive discourses which went on unto ten-twenty minutes which were not very usual at that time. This new type of music is described by Scaruffi by following terms;

'The cats grew excessively long, over shadowed by a common monotone darkness, a sense of impotence and claustrophobia, torn by guitar distortion and abused by foul language. The free-form feedback jams, hyper-dosinte grating holocaust that collapse into lowest level of emotionality' (Scaruffi, 2003).

These two albums are the most noteworthy ones, but they also later released 
two albums called Velvet Underground and Live. Those latter albums do not carry the gravity and discourse as the first two did.

This essay comprises of very few of their long poetic discourses in the form of acid jam. However, many of the shorter and well structured three minute (or bit longer) lyrics which fall into the jazz-rock category will be analyzed. The lyrics which have been selected to evaluate here are 'Sunday Morning', 'Femme Fatale', 'Venus in Furs', 'All Tomorrows Parties', 'Heroin', 'I will be your Mirror' from the first album and 'After Hours' and 'Pale Blue Eyes' which were in the later albums. Though the lengthy and experimental titles are the real masterpieces, I choose the shorter ones too because of their popularity and widely discussed. However much those are historically important, in the scope and the physical space of this study; all the lengthy songs cannot be discussed here. For the convenience of the shape of this study, I first discuss Velvet's short lyrics such as 'Sunday Morning', 'I'll Be Your Mirror' and 'After Hours' which are of more balladic nature and fairly easy-listening, and then go into some of those longer, chaotic and more deliria category such as 'All Tomorrow Parties', 'Venus in Furs', 'Heroin' and 'Femme Fatale'.

\section{Sunday Morning}

The song 'Sunday Morning' in the album Velvet Underground and Nico (1967) relates to the 60 s typical compositions structure of the pessimistic psychedelia of the contemporary human existence which ideologically stood against the optimism of rock music in general and of the San Francisco psychedelia in particular. The entire lyric explores the contradictory human existence at present in which the organic realities of the world is either forgotten or ignored by us to accommodate ourselves comfortably turning our back to the modern day human adversaries. The psychological tensions that are generated through physical torments are temporarily forgotten to by means of what the establishments such as religion promote as consolatory words. The individuals pretend that they do not to see the very restlessness that the society has subjected them to live with. They follow the daily pattern that they have been trained to and do not question anything as if everyone is in a kind of an agreement not interrogating anything. The title 'Sunday Morning' has also a religions connotation i.e. to 'mechanically' perform the Sunday mass at the call of the church. The religion makes us forget the fact that too many bad things are happening around us and we have to be patient without disobeying the God's wish. We must be out of harmful things. Revolutions, uprisings against the unjust are not allowed in the name of God. On the contrary, in reality, in the name of God and justice, it has generated countless wars, hatredness and deeper divisions and wounds in humanity. That situation can empirically be perceived as the destruction of the humanity in the form of subjectification of individuals, forceful suppression which demands obedience, ethnic cleansing 
in the true history. This catastrophe was further facilitated by the intellectual laziness of the generation and backwardness of the public who does not care. All this is condensed in the line;

'It's just a wasted years so close behind'

This history that we witness in this century is the history of sadness and suppression. Humanity could not achieve its goal of prosperity. The world is so divided and all hope is gone. These were the years of pure human desperation after two Great Wars. Man was in the threshold of the Cold War which left the humanity in absolute fear and hopelessness about what tomorrow will be. The traumas of recent past have still not been healed and to which destination the societies were lending have, hitherto, been obsolete. The contemporary consolation of the past and the present has also been constantly barred by, 'someone around you who will call its nothing at all'. Velvets here ideologizes the ordinariness of the individuals who always ignore the reality of suffering and the cause for suffering which the present entertainment culture has a part in diluting the tension by way of petty happiness of its fetish goods. In the upcoming consumer Capitalism, nothing was serious and everything was entertainment-oriented including you own destruction (Zizek, 2006b). The awareness of destruction is further dissolved by the ignorance which claims that 'it's nothing at all' and the submission of the subject to such myths is shown by the line;

\section{"Sunday Morning and I'm falling I've got a feeling I don't want to know"}

We now live in a society in which myth has replaced the dominance of the ideology. This is a post-ideological era (Zizek, 2008). So, the individual have given up the desire to be conscious of the suppression and subjugation by submitting to the feeling that seriousness is not wanted and things can be taken for granted, which is what is repeatedly said in the contemporary technological civilization. The ideological education of the previous generation is no longer applicable. The direction of the social consciousness of the individual was altered initially by the religion during the modernity but today it is done by fetish consumerism. This blurs the material and empirical consciousness of a subject about the elements of the suppression. But we must also realize that the technological society has a capacity to enhance the awareness of individuals by means of advanced technical devices of the digital technology. These songs can filter to individuals through such means surpassing the geographical and time restrains of the previous era.

The next line of the song awakens us from the blindness the very reality of the day-to-day life. The Velvets illuminate our tendency to ignore it and try to 
remind us how feeble can be when we are caught in such 'empty myths'. They transcend a meaning for us who have just become neutral participants of what is ignored as the human suffering that we experienced.

\section{'Not so long ago'}

The things happened not so long ago but we do not remember them now. The repetition of the line;

\section{'Watch out the world behind you'}

is a clear eye-opener to the public who are reluctant to review things. The Velvets warn us that if the negligence continues, the things will get worst. It is clear demarcation for the audience who are unconsciously determined not to be aware of the suffering but to come forward to change the world for better. The Capitalism will give 'small happiness' to everyone through its fetish commodities. However the inner contradictions disturb the very existence of the man. 'It is just a restless feeling by my side' shows this ex-introvertness of the subject. Though the reluctance is inside, when you look at the world to see that there is ugliness everywhere, what is suppressed comes to the surface.

The song never represents any political ideology but grasps the very reality of human contradiction of clinging to the comfort of an ideological convenience. The man's attempt to ignore the reality and pretend not to be aware of the suffering is cynically but undisturbedly turned down in the song. However, man has fallen into the trap of unending mythologies that forsake reality and he is now not potential to make aware himself and others by finally falling to the pit of laziness and to the indefinable misconception of not knowing what to do. Although sometimes it appears that the subject gives into the ignorance but actually it does not; i.e. to mean that the song surpasses the existential acceptance of,

"Man simply is..he is what he wills" (Kaufman, 1989)

As Velvets wants us to look at things by exploring more than what they superficially appear to be, they seem to command us to 'watch out' so that we are to perceive the world abandoned by us, which we have to care for. The song stands against the conventional optimism (example Here Comes the Sun or Good Morning by the Beatles) of beauty and charm in the morning in the face of more hostile, competitive and antagonistic social relations. Here the Velvets de-aesthetizes the entire rock and blues tradition by mentioning nothing of any romantic nature that has been the practice of the poets and lyrists for centuries. The studio version sounds more classical, compact and easy-listening and perhaps one among the few Velvets ballads which has an attractive and simple 
melody. Scaruffi puts this song in more classical atmosphere in his remark,

"The cold lunar landscape of Sunday Morning, a tenuous fairy tale told by a cursed fairy with finite nostalgia, with a refrain suspended in emptiness that wraps itself around endlessly in a thick jingling of metal." (Scaruffi, 2003)

This song detaches from the reality and, at the same time, combines the reality into a sad melancholy but not with no hope for a better future, though they do not entice the audience to do away with the evil of the oppressor, no they provoke the listener to act against the suppressor, but they simply and empirically show you who are you and what you are made of. Though the Velvets were not existential, this attitude fits more to the existential understanding of the world.

\section{I will be your Mirror}

This song also appears in Velvet's first album Velvet Underground and Nico (1967) and reflects the facelessness of the individuals in the contemporary society where people do hardly find something to mirror who they truly are. This is an 'identity-less' and 'mirror-less' consumer society which absorbs everything into it and does not reflect anything (Baudrillard, 1983). Here, the Velvets volunteer to be a mirror from which their audience makes out who they themselves are and the very elements that we are made of, but of what we all have forgotten. If people cannot figure out what they are, Velvets go further to become even the rain and the sunset; the denotations of the nature; the very elements with which the humanity conquered in the early history in discovering the 'otherness' in making the culture. It is also reminded that when those individuals are back home not knowing that they are actually back, Velvets looks into the possibility of becoming the light at our doorstep to show that they have returned back home; to the place where we have started the journey. It also appears that we have returned without fulfilling the needful of a necessary battle of making a better world. This battle still remains unfinished today, even after nearly thirty years of their career. However, in this song, the Velvets disclose the true, selfless and egoistic soul of the individuals of the era.

We think that we know ourselves but Velvets display their wider awareness about the humanity by exploring that the real inside of everyone is either 'shaken' or 'twisted' or 'unkind' that we never see the suffering of 'the other'. However, the word 'twisted' seems to mean that the individuals are shocked by the outcomes of the era. Man was completely convulsed by the outcomes of the wars and by the waves of the post-industrial commercial capital and its de-humanistic market forces. Is that the 'twist' and the 'unkindness' that is mentioned here? Obviously, no human relationships have been left in this market orientation. As Marx mentions in the Communist Manifesto that, 


\begin{abstract}
"The bourgeoisie, wherever it has got the upper hand, has put an end to all feudal, patriarchal, idyllic relations. It has pitilessly torn asunder the motley feudal ties that bound man to his "natural superiors", and has left no other nexus between people than naked self-interest, than callous "cash payment". It has drowned out the most heavenly ecstacies of religious fervor, of chivalrous enthusiasm, of philistine sentimentalism, in the icy water of egotistical calculation." (Marx and Engels, 2000)
\end{abstract}

Human differences and their internal dimensions have not been understood and given due respect in this world but absorbed into the capitalist's market as sellable consumer goods. The true human nature in their relationships has been taken off from the core by the over-determining external appearance of the objects.

Velvets volunteers to offer their hands to guide us in the right pathway. They employ an ultimate combination of aestheticism, political conception and awareness to awaken the audience from their blind adherence to the current social structure.

'Let me stand to show that you are blind'.

What is appreciable here is that Velvets fearlessness to criticize their own listener without considering that they might loose their popularity in the process. They bring out a harsh criticism to everyone including their own listeners, whom they thought, were blind to the dark nature of the humanity. This was what the Beatles were afraid to do and remained extremely popular for the next decade or so. The Velvets took the path less taken.

'When you think the night has seen your mind'

Night is generally metaphoric for the release the sexual libido. The nights in the major metropolitans are seductive and supportive of that libido, since sexuality is chief way to maximize profit. The above line is about the false consciousness of the individual who believes that the romanticism and the gloominess that the night generates and unleashes the motives to release the sexual libido is the true catharsis of the inner galvanized sufferings. The true blend of intellectual motivation and avant-garde musicality to dig out the subconscious of the urban kid has never been authentically depicted before the masterpieces of Velvet.

Velvets extend their criticism further to envisage that we are not only unaware about, as mentioned earlier, the external social realities of the day but, 
unforgivably, and unaware of ourselves. We, at least, do not know whether we are beautiful or not. Velvet also commands us to put down our hands which we always raise affirmatively to show that we know 'things'. It semantically carries two meanings i.e. we raise our hands to show our presence and to show that we know and, on the other hand, to signal for help. All that can be applicable here in regard to the present conditions of the humanity. We are 'prudent' and ready to show that we are there to help in any adversary of any kind but, in the real needful, we are even not to be seen but go home and stay comfortably participating in the superfluous, digitalized media reality. Velvets ask us to put down our hands since they 'see' us. We do not want to say that we know ourselves since Velvets are in a pre- assumption that they have realized the pretentious nature of today's man and, at the same time, there is no need to raise our hands in showing our suffering since that has too been realized by them.

As we do not see our own beauty, they are ready to become the light in our doorstep or even to become the eye in order to show ourselves and, most of all, the world and its degradation. They come forward to give us a hand to walk in the darkness of the present human civilization. This signs optimism in the extreme pessimism that they advocate in their songs. We are not only blind that we cannot see anything but the world itself is dark which prevents us seeing anything. The ideological blindness, on the other hand, refrains us from 'seeing' anything accurately. Velvets show an excessive cleverness in showing both the inner and outer darkness of the time when no light of intellectuality is found nearby. The leading ideological frontiers such as existentialism and expressionism were incapable of grasping the world realities and changing them. This song is a good example to display Cale's ability to divulge the degradation and the dualistic nature of the humanity today. He cleverly and deliberately combines beauty with the salvation of evil. Further, this lyric produces symbols of ideological laziness to discover a new pathway of intellectuality to understand and alter the mystery of misery and extreme degradation of inner human values.

\section{After Hours}

Before beginning the discussion I would like to give you two brief online commentaries about the meaning of this lyric. Authors of these writings are unknown but the original URL is attached for further investigation.

\section{Commentary One}

'The song is about After Hours bars of which there are plenty in New York City. It's about the other world that exists there where you don't have to face the reality of what's outside so long as you 
keep the door closed (in realty and metaphorically). It's not about any particular romance or whatever it's just about the kind of people who hang around bars at 3-4 am when everyone decent is asleep. Everyone looks good in the dark. For a good perspective on this song listen to the Maxs Kansas City album where Reed sings it, especially the final verse. If you want to view it in a wider context its about anyone who doesn't want to race the reality of something (in Reed's case the band was breaking up when Maxs was recorded) and hides away from it.' 9

\section{Commentary Two}

'This song makes me think of virginity. the narrator wants to see what it's like ("all the people are dancing and they're having such fun"), hope it will happen to her ("i wish it could happen to me").

Losing virginity a toast to never (never be a virgin again). It sounds like she's about 14 years old or something and very curious. she figures that experiencing sex now will not lessen the effect of when, someday, she finds someone that she actually loves (Oh, someday I know someone will look into my eyes; and say hello -- you're my very special one--’).

And finally, day symbolizes purity, clarity and goodness. The night (that could last forever) symbolizes vice/sin i.e. sexual "immorality" - once the day ends, it's night forever.' ${ }^{10}$

It seems to me that both two commentaries are worth studying since both can be semantically deconstructed with equal justifications. The first author does not go beyond the contexts of the making of this song and the background on which the composition was made and so on but the second author attempts to bring out some external contexts to re-define what is not said in the song. In a feminine way, she relates the connotations of the song with virginity that underlies purity. The lost of virginity means, under Puritan values, that one can never regain it. Further, she articulates that with the real romance which is worth offering the virginity for. The Victorian Puritanism and the morality that it advocated has been questioned to a certain extend by the second comments that can go with the semiotic interpretations of the sort of meanings that Velvet advocated for.

But the song, I think, elaborates two major themes i.e. the restriction of a female's freedom through masculine institutions (such as morality, power, and family) to '(un)make' the woman and her struggle to become herself. The societal restrictions and ignorant unacceptance of diversified sexualities 
in humans is another aspect in question. The long-lasted, over-determined sexual mode in the human history is heterosexuality (Foucault, 1972). In the face of the hegemonic heterosexuality, the other ways of sexualities such as homosexuality, lesbianism, exhibitionism and transvestitism and so on will be either secondary important or, most of the time, oppressed, unaccepted and excluded from the mainstream. In such exclusion, a transvestite such as Lou Reed will find the hostility of the dominant mode as suppressive or unidentifiable. The phrase 'close the door' means the closure and antagonism towards the other gender developments of individuals against heterosexism.

'If you close the door, the night could last forever', shows us the forever unacceptance will suffocate such an individual forever. When the acceptance of a different gender development is deliberately neglected or unconcerned, the 'ordinary happiness' that prevails around the speaker intensifies the pain and isolation. Then it becomes an identity crisis of not being able to move in the line of the 'ordinary' social mobility. On the other hand, when this is compared to the restricted freedom of a woman who longs for freedom outside the domesticated household setting of the patriarch, she too cannot bloom with her inner potentials and diversities and, thereby, the sunshine of the day will be barred to her forever. Night denotes the sexuality of the domestic life in which she has to perform the 'duty' of 'giving in' but the day means outside, outgoing, and non-domesticated patriarchal human world. The domestic night will then last forever and the human day time will never arrive to her.

However, the restricted life and a drive to regain individual freedom, whether heterosexual or transvestitism or any other category, is connoted as a key theme in this song. The night that lasts forever destroys not only the wine glass and the toast. Though appears simple, the song connotes many meanings that can be interpreted in many ways to serve different purposes. The next line immediately confronts with the surface mannerism that hides the hypocrisy of those who would finally say, 'you are my very special one'. The speaker thus becomes a special character since she has not been to the outside world and others have not seen her in the town in the day time. But the ordinary world moves as usual with its machinery movements; the Cadillac and bars go on to make things happier and the 'innocent' people who know nothing about the injustices and de-human nature of the immediate reality just gather in the city and the subways to celebrate in orgy. Can they forget the fact the there are others who struggle to be a part of the happy world that they share? The deliberate and spontaneous social movements, unorganized mob, social arrangements, fights, romances, urbanization and its merits and demerits including evil, industrialization and pollution (gray in the train), alienation and tension are all part of the life we share. This is the life outside the door. Once she does not face the reality, she obviously cannot say 'hello' to anyone 
since she does not know them properly. Thereby, she will not come to know anybody, or fall in love with someone and discover the ambiguities and beauties of the life. The joy in success and the pain in defeat are not part of her life. The darkness of idiocy will remain inside the walls forever.

Even though this song did not receive much of a reputation and respect as the early Velvets' masterpieces, the male domination and Puritan homeliness (Garrett, 1992) is effectively and bitterly questioned by this song very much similar to the radicalism of the previous works. This theme becomes an iconic universal slogan of the contemporary generation who wanted to decisively break away both physically and ideologically from the previous generation and from the patriarchal parental home where they were supposed to live as decent and obedient followers of their parents. The anger against 'the masters of war' made a greater generational and political gap between the two which never pacified after.

\section{Venus in Furs}

This song too originally appeared in Velvet Underground and Nico (1967) which was recorded in their California Tour in 1966 and released in the following year. It reveals the moral misery of the nocturnal masses of the underground metropolis. The masterpiece is reputed as one of the most prolific and fetish songs ever produced by the Velvets. The song has its mystic ability to excavate the freaky sadomasochistic element of the dark underground metropolis where a fantasy of a pervert becomes materialistic in the hand of a whore or any in seductive female body who hovers in the street. The freaky and fetish appearance of the mistress whose lash has the magic ability to cure the heart of a pervert with her sadistic hits with the whip is initially portrayed to the listeners. The shiny boots of the whiplash girl-child with a bell (Lolita syndrome?) reminds us of the paid sex labor of the fetish, immature genre of today's pornographic industry.

The fetish appearance itself is suggestive of her tactile stimulation to get caught in her seductive attraction. She would then dominate over man by taking control of man's innermost and profound psycho-sexual drives to become his fantasy object in such a way that he may never leave her. It actually addresses the 'dirty fantasy' (F2) or the second level of the fantasy (Zizek, 2006a) which is essential to maintain the 'beautiful first rate fantasy' $\left(F_{1}\right)$. The guilt of the second fantasy and the 'conscious' sinfulness of the relationship will never allow the speaker to remain 'balanced' forever. Her association will bring a catharsis to confess the guilt. The relentlessness that she is pleaded to apply upon the subject has a ritualistic therapy of purification from the sins which brings the psychological contradiction to a point that we are unable to clarify through rationality since such a meeting of the 'real' is linguistically unsignifiable. 
'Don't forsake him, strike dear mistress and cure his heart'

The mixture of costumes and sexualized fetish objects create the sense of downy sins in the nocturnal street life which always has the typical habit of providing traumatic sexual arousals in the inner consciousness. The interior guilt demands purification. On way of purifying is the self-inflicted-pain or sadomasochism. The pain will purify your sinful body. The agent of this purification is the female body which is a traumatic real who is represented by a femme fatale. Her image here, in this song, resembles the intrapsychic with a strong psychoanalytical connotation. The moral principle of what is right and wrong collides with the reality principle. The present market knows how to commercialize such inner fantasies. It merely categorizes such into genres and makes an enormous amount of money out the fantasies of the individuals since the fantasy can ultimately be commercialized.

The fetish and the sadomasochistic nature that appears here can be compared with Rolling Stones' popular song Rock Off ${ }^{11}$ in their album Exile on the Main Street (1972) which says;

'Heading for the overload,

Splattered on the dirty road,

Kick me like you've kicked before,

I can't even feel the pain no more.'

The horrible tension between the need for fulfillment of desires and the restrictions to deny the desire create a 'split' subject. The intensity of desires is strongly portrayed in the Stones' song but it lacks the ideological direction to guide the listener as to how he should divert his own desires rather than going after the same woman again and probably exploiting her again. What Stones' want is the release of the sexual libido but the Velvets have at least their own 'guiltiness' about what they do. Velvets go beyond from the point of the bodily fulfillment of the desire. Nevertheless, the Stones' song was not a pop ditties designed to an easy-child-listener. With the line, 'what's the matter with the boy', it is difficult to distinguish whether Rock Off is about a gay experience. The extreme tiresomeness of the monotonous day life in the mechanical city context with no human touch but only commercialized relationships with each other is vividly captured by the lines below. The never ending sleep denotes a physical escapism.

'I am tired, I am weary

I could sleep for a thousand years 
A thousand dreams that would awake me

Different colors made of tears'.

These are some of the most beautiful and memorable lines ever written in rock culture, which symbolize the agony and the delirium of the day which has been 'snapped' from this generation. What is left for them is an unfulfilled dream and Velvets prefer to sleep with a colorful dream in a fanciful world. A better world for them is just a dream. You cannot now fight with a system which seems to never end. It maybe they resort to drugs. It makes your fantasy more colorful. At the same time, the 'psychedelic trips' can also mean a sleep for a thousand years as they detach themselves from time and space barriers of the material world. They would not intend to come back (in case of an overdose) to this ugly world. The dreams become colorful with their drop of tears that come from the pain of their inability to identify themselves with the world they live in. They choose to depart from it rather than comment on it. If guilty, there is a punishment in her hand. That leads to another guilt. Life is paradoxical.

'Taste the whip, in love not given lightly

Taste the whip, now plead for me'.

This is also, according to Velvets, not an easy love since this type is not quite common compared to an accepted heterosexual relationship. On the other hand, The Velvets give a sufficient respect and gratitude to the woman who is giving sexual pleasure to them compared to the urge and the quickness in Stones' Rock Off. The harassment that is inflicted through the whip is revered and kindly asked to be repeated. The mention 'plead for me' is, in a way, a form of spiritual request for her to make him to be purified under the sharp hits of the whip. She is a satanic inference to make 'that' plead instead of God. The tribalistic practice of chastising the possessed of a disincarnated entity and releasing the subject from the burden of the sins is metaphorically exorcised here. The Venus in Fur brings the 60s generation to an ultimatum of their life paradox of guilt and purity.

The theme of the song stands as one of the major psychedelic influences to entire rock music. The song contributed to the initiation of more meaningful, self-expressive and pessimistic attitudes to the arena of rock for the next couple of decades, especially to the psychedelic 70s. The song was never an anthem of protest or not even expressed clear-cut affirmation to the popular angst and generational anger of Dylan or Stones or even The Who. Instead, it declares a unique self-expressive inner majesty that none of the contemporary protest songs had. Though highly personalized (due to the self-indulgent heroin culture), the song never missed the dream for a better world, where 
the evils of the metropolitan would one day disappear. The 'dream' becomes a delirium of psychedelic doses of heroin since it goes beyond just a dream of an ordinary man.

\section{All Tomorrow's Parties}

This song is the third track of their debut album Velvet Underground and Nico (1967). The song is commonly hailed as Nico's finest masterpiece, 'a towering aural monument to ephemeral glamour, with the pulse of dread and Reed's destabilizing frantic guitar' (Scaruffi, 2003). The inner conscience and the protest towards the infinite exploitation of the female body to create marketable fantasies in customers has been the main focus in the song.

The song starts with an eye opening rhetorical question of what costumes shall the 'poor girl' wear to all tomorrow's parties, where people stare at her as she caters to 'the fantasy object' (Lacan, 2004) of the male subjects, who offer her something to wear for all tomorrow's parties. She must cover herself from the cloths that she does not know where they come from. We assert meanings to her dress as 'cute', 'sexy' or 'elegant'; all marketable in tomorrow's fare. Her body is sold today to commercialize the garments tomorrow which may be a party dress for tomorrow's never ending parties. Everything is beautified and from which agent we buy the beauty tomorrow is the problem. The 'happiness' (or ecstasy) in this age is determined by being more and more beautiful and youthful. We got garments and costumes for that purpose. We buy them to make ourselves and others happy. The market is right in the middle of our desire to be beautiful and to survive in this world. The dress, therefore, has meanings and stimulates power relationships with others as long as it can 'seduce' others. It bypasses the 'class signifier' of modernity. Through dress now one cannot derive anything and it is trans-class now.

But when this girl has to wear a dress to which she cannot assert a meaning, she confronts with an identity problem. It is obvious that if she is a model, she is used as a hanger to hang cloths irrespective of her liking to the dress. The sudden introduction of the midnight coming around shows that she becomes uncertain about the midnight, which stands between the daytime and tomorrow. The tomorrow is the sign for future and the future is not clear for the poor girl and that future will never come. The adjective 'poor' can simply mean poverty but in the context of the song it means more than the financial inability. It is nothing but the poverty of the soul, which has been battered in such a way that a recovery is impossible. It also means the indecision of choice and the uncertainty of future. Her powerlessness to make her own choices too can generate this pathetic helplessness.

An online commentary on this song once mentioned about the Sunday clown that, 
"Midnight is the doorway between today and tomorrow. Tomorrow, the future, is what she's always worried about (remember, she has far to go). As midnight and tomorrow approaches, she gets panicked. She realizes she still cannot go anywhere acting how she might act, and decides to turn to God. I believe "Sunday's clown" is Jesus. Not that Jesus is a clown, but that the way his image is produced can easily be a costume and any costume can be described as clown-like. She turns to a "savior" and mourns her behavior, hiding from everyone and crying. Even now though, she is hiding when is crying. Her mourning is the only thing that is nature to her--everything else she picks up from others--and even that, she hides. ${ }^{12}$

If the song means Jesus for the 'Sunday Clown' then the text goes into an antireligious connotation to mean that it humiliates Jesus who is also, in a way, a 'hanger' to hang whatever clothes people wish to. This produces a variety of funny images, but Jesus silently waits to be used by such devotees. It is the lack ideological resistance which creates this 'clown image'. If the song directs a man who takes care of her as a guardian, then it again criticizes the inhumanity behind this act. Her 'cry behind the door' shows the agony of her inner collapse and the helplessness that is not clearly seen by those who only see her party dress. She is just a body. The answerless rhetorical question 'why silks and linen of yesterday's gown to all tomorrow's parties' shows the rotation of the same old linens to hang in her body but again she has to cry 'behind the door' after getting back to the Sunday's clown at the end of the day. We all live in a society where ideologies have died and everything is permitted.

Now no one mourns for her in the way they used to mourn for Christ who was in pain. But everybody now enjoys the view. The last segment of the song brings forth dark images of a black, mournful, gloomy and alienated soul, whose spirit rigorously seeks to rescue from the endless repetition of the commercialized fetish to cater the stranger's fantasy. The song is a masterpiece to display the spiritual degradation of the contemporary soul, which was taken away from the cyclonic devastation of the commercialization, which denunciates all uniquely celebrated values of the good old days.

\section{Pale Blue Eyes}

Man cannot escape from the fantasy painted in his mind from early childhood psycho-sexual development. Woman, as a fantasy object creates in man an endemic inescapability that will force him to stay with it as long as he meets the body element for the fulfillment of his desire. The fantasy will benumb him due to the unsignifiablity of what she is and what she is made of. This is 
in Zizekian terms, 'the real' (Zizek, 2006a). The fatalistic dream is like the female object portrayed in the song 'Pale Blue Eyes' which appeared in the album Velvet Underground (1969). It must be noted that, by this time, the true voice of the Velvet Underground was becoming obsolete. It was also, by this time, that the romantic themes of the beatlemania ditties have completely been taken over by nostalgic female love and separation. However, this song de-romanticizes the empirical experience of the detachment of love and the traumatic indulgence that the loss causes. The line,

'Mostly you just make me mad'.

shows how the appearance will make the subject deviate from the conscious world into an unsignifiability (madness). There is recovery, but recapturing the loss which forces him to hang on to the deliric pale blue eyes (the blueness which would have been caused by psychedelic drugs or heroin). The speaker compares her to a mountain top and to the peak which is the excessive sublimation of the subject's fetish desire. The unreachable apex contrasts with the unfulfillability of the meeting of the fantasy. But to sustain the desire one needs to give a try to reach the peak which is impossible. You no longer live if you do not have her but the unreachability and the unretainment make her further sublimated. That is said in the line, 'if I could make the world'. It convinces us that the speaker wants the world to be purified and re-made to accommodate her in a better life and to make her in a mirror to reflect us all including the narrator and herself, so that we all could see each other. The speaker's desire to make the world a better place is again obvious, despite the metropolitan's manic deformities to reduce all that is human to fetish commodities. This commercialized nature, in her words, is that 'money is like us in time'/ it lies, but can't stand up' and eventually 'skips the life completely and stuff in a cup'. The seductive and diluting nature of money is metaphorically displayed to us like a female. The hazy atmosphere of the metropolitan which has been overshadowed by a common monotonous darkness (Scaruffi, 2003) and the loss of life to the disintegrated, blood-sucking, hyper-digitalized humanity in the libidinal economy are never philosophically sited in a song other than this. The sign of degradation and the decline in the life are the 'down for you is up'. All that is forgotten in her pale blue eyes but the eyes are not real. This paradox is never solved in the metropolitan. The guilt between her marriage and the drive to break the law of fetishism takes over everyone. The metropolitan sins continue to occur and the moral paradoxes too remain unsolved forever. The human subject is completely de-humanized and alienated residing to drugs perhaps to run away from the guilt. The sin and the devil are celebrated in a ritualistic triumph. 


\section{Heroin}

The Velvets made a drastic cultural and behavioral difference in their very appearance in their attempt to go beyond the contemporary habit of the use of hallucinogens such as LSD (lysergic acid diethylamide) and other psychedelics by using a more sinister substance like heroin. Heroin was a post-Vietnam war phenomenon in America and, in that catastrophic war, nearly 42 percent of soldiers who served in Vietnam were addicted to heroin, and even after the war was over, many continued to depended on this (Burlow and Durand, 2007). Youngsters used to get to this 'trip' in their temporal escapism from the trauma of modern life. Heroin, little by little, became part of the dark side of the urban life of the youths who impaired the pain and trauma of the urbanite, desensitized, excessively painful underground, which ultimately made a platform for their cathartic self -expression which has fatalistically ended up in the hands of drug traffickers to maximize profits in the advanced capitalism.

It is with this contextualization that we analyze the song Heroin which appeared in the album Velvet Underground and Nico (1967). The song makes no specific impression on the society on its being and functioning as part of the social fabric in its hazardic de-humanization of the commercialization process. The song does not suggest anything such as to make a deliberate intervention in changing it, but shows how it remains so sinister and destined in the lives of the youths. Velvets pessimistically reinforce a notion that we have nothing left to do but to indulge in it. But they depict the reality in such a naked and forceful manner that we ultimately cannot keep our eyes shut to the harsh realities of the modern life. That impression is more important and eye-opening than making a fake slogan to stop it.

The first stanza narrates to us the deliric indulgence of the hyper- real psychoactivity in hypnotizing the fantasmatic kingdom and Jesus (both which cannot be signified) and to travel through the beauty of the nice girls in heaven (not the 'polluted naughty ones' in reality) towards death after the injection of heroin to the body. The reality contradicts with the hyper-real fantasy of a better world. It is only that dreamy world that the individuals feel 'heavenly' but not the seductive and decadent earthly world which they deny to identify with. This song takes the external adventure of obtaining drugs into the internal realm and portrays the seduction of the addiction with such power, beauty and grace that makes it all the more frightening. You must feel the blood warmly flowing in the body to feel that you authentically exist in this world. It must flow in the body with such an utmost heat that it finally nullifies your soul. No religion, no preaching, no philosophy will substitute the effect that heroin has on you. Heroin remains thereby yet another 'unsignified object' such as a kingdom or Jesus and it will make you forget about the traumatic existence of time and space. The masterly heaven is replaced by a sinister and satanic substance. 
'I wish that I was born a thousand years ago

I wish that I'd sail the darkened seas

On a great big clipper ship'

The actual but hyper-real wish to fly away from the territorial (space) boundaries of the current emptiness and solitude to a dream land by a clipper ship is depicted in the second stanza. It clearly says that they want to sail away from this evil city where individuals are no longer human, to another nostalgic entity free of such vision. This notion shows a certain degree of escapism which is unavoidable. What else can you do if you are extremely helpless? On the other hand, they want to disguise themselves as sailors when they go to that land, as they do not wish to carry their true identity which has been distorted to such an extent that they ultimately hate it. Before going to the final stanza I must mention here that whatever emphasis put on heroin, the song never thematically fails to ignite the fire sparks for those who wish to initiate in some way to make the world look better.

The final stanza stands for the magnitude of the importance that has been ascribed to heroin, which is compared here to life, wife and death. Heroin goes to blood, then to the brain and neutralizes the ordinary feeling of life and improvises a vision that is beyond the descriptive real; of an unconscious delirium. The hypocrisy of the politicians, seductive individuals who may sell anything for money, soulless tormented libido, emotionless mechanized romance and lust, hysteria, war, vandalism and decadence of the generation who wasted their lives in the street are all forcefully forgotten and made to enter into a colorful and prolonged delirium.

'Then thank God that I'm as good as dead Then thank you God that I'm not aware And thank God that I just don't care'

The Velvets are not only pleased that they escape from the harsh reality but succumb to the forgetfulness that this substance has created in them not to be awakened to the bitterness of the reality again. They may vanish into the sinsterness of heroin.

The infinite escapism that is so apparent in this song does produce an ultimate objectivism to remain in the indulgence but, at the same time, it functions as an eye-opener to the core of the very making of this social system, which kills the humanness of individuals and transforms them into selfless machines of the production force of commercial capitalism. The fatalistic questions that this song raises, such as identity crisis, politics, the binary of illusion and enlightenment and the sin and redemption are the very areas on which the present civilization must attempt a swift and radical re-thinking to revolutionize 
the politico-cultural quagmire of modern life. The Velvets as radical prophets reveal a modernistic truth in an extended fashion and nihilistically demand a verdict upon which a salvation and beauty can be restored to the benefit of the future generations to come.

\section{Femme Fatale}

The lyric Femme Fatale portrays the image of a Lolita-type female who has the magical ability to cure contemporary sick male subjects, whose inner souls are lost to the apparently lusty, commercially uplifted femininity. Cosmopolitanism and its sins, alienation and class seclusion have made youths drive to the underground, which is the necessary result of modern capitalism. Scaruffi relates this song to the personality characteristics of Nico in saying that,

'The smoky vision of Femme Fatale, set in a depraved Parisian bistro, soaked in delicate melancholy whispered by Nico, part angel of evil and part mournful damned' (Scaruffi 2003) and, 'Nico, naughty brat and tenebrous angel, elegant and sinister, fatal and elusive, emits tone deaf Teutonic laments in a neutral and worldly-wise tone' (Ibid).

Her personality goes much with the real content of this song. Nico is a seductive, drug addicted beauty who had the ability to make males find their 'salvation' with her sinisterness and lusty appearance. The powerful image of this fatalistic femme fatale seeking you is initially portrayed in the line,

'Here she comes

You'd better watch your step

She's going to break your heart in two'.

Her ability to break your heart and to make you fragile in front of her is vividly depicted through these lines and the care that someone has to take in dealing with her is also signaled here. With her false colored eyes, she can build you up by stimulating your desires and then, without any remorse, can destroy you by eliminating the very desire that she planted in you minutes ago. Fragility is the very character of modern commercial culture. Temporariness is the very nature of consumer society. The life span of a human relationship is reduced to the time that we take to consume one commodity and go to another in this new age (Bauman 2004). Once the desire of an individual is destroyed, his or her very drive to live will also be terminated and will subsequently become an insignificant 'clown'.

The next harmony of the song re-tells us that everybody knows about how she is and what she does to please herself. Then the lyric opens a very important as well as controversial segment of the narration i.e she has given everyone a 'number' (like in a prison or in a concentration camp) and, thereby, nobody can escape from her sight. 
'You're even in her book

You're number 37 have a look

She is going to smile to make you frown

What a clown'.

It seems that she mocks at the entire world by earning her joy and happiness at the destruction of the other. We can frown at her by amusement or by anger or by disgust but nothing can make her angry or destroyed since she exists because of the desire of the other. She exists because we desire her. It is the male world which created her and it is the male world that she laughs at. It is the male world which gets destroyed one day.

The poet also reminds us that 'she's from the street' which shows her urban background and her familiarity to the city and its evils. When the line, 'before you start, you 're already beat, She's going to play you for a fool' is heard, what is felt by the listener is the inevitable defeat that is destined in front of her and the immense power that is within her and her act. If she employs 'seduction' to attract the other, it is because she wants to make you feeble. According to Baudrillard seduction by nature,

'always seduces in order to perpetuate seduction; it is always its own end. To seduce is to weaken. To seduce is to falter' (Baudrillard 1979).

She weakens the male ego by seduction and destroys him little by little by taking him to her cobweb. She makes the male meet his very desire with delay or waiting and one does not need go in search for his desirous object (mostly the female body). With the meeting of desire that males have been dreaming for, they actually meet their symbolic death but not the pleasure. The pleasure must be earned by distancing from the pleasure object and regulating it. The symbolic is both the pleasure principle which regulates the distance from the Thing, and the death drive which goes "beyond the pleasure principle" by means of repetition; in fact "the death drive is only the mask of the symbolic order". So, there is deep psychological base for her to reside to kill the male with her intrigue use of seduction.

\section{Other Important Songs:}

One of the most admirable songs not lengthily discussed in this paper is the monumental 'Lady Godiva's Operation' (1968) which discusses about a transvestite sex reassignment surgery (personal experience by Lou Reed). The same deliric mesmerize of those of the other songs inspired by heroin are portrayed here as well even though the contexts differ. The post-anesthetic phase of the operation and the over-hearing of the conversations of the doctors and other staff literary fix with the post-injection phase of heroin. The blood, blades, fear, screaming uncertainty and final healing are depicted in such a 
manner that the subject's helplessness in front of the master (doctor) and the dependency of a patient (may be we all become such subjects one day) and the new identity that one can identify with, after a successfully completed operation are detailed to a perfection of that of an epic travelogue. The song has strong signals which metaphorically symbolize the submission to the death instinct that is also an inescapable traumatic reality within us.

'Sister Ray' (1968) too makes a fabulous sadomasochistic witness of the sexual frustration of the youths of modern day. This song, according to Scaruffi, 'remains as the ultimate, definitive masterpiece of rock music (Scaruffi, 2003). The seduction and perversion are again shown in the line, 'who is busy licking up her big man' and 'too busy on sucking on a ding dong'. The sexual deviance and the commercialized, mechanized and emotionless body engagement depicted in the song undress the Puritan middle class values and the hypocrisy of the older generation to such a naked extent that no other song has done before or will not be done for decades to come. What, in short, Velvets plead is death, which is another authentic drive to destroy ourselves.

The repetitive mantra version of the 'Here She Comes' (1968) portrays the infinite waiting for a fantasy female object from the wood. The true female from the city is not to be even dreamt. The endless repetitive nature of a mantra being enchanted and empowered over and over for the fulfillment of a hope swings between uncertainty and fulfillment.

The brief but powerful 'Jesus' (1997) is an open appeal for help on behalf of everyone fallen out of grace and have ended up by being weak in the endless agonizing trauma of modern life. Jesus has to emerge again to cure our broken souls and guide us to the right path of redemption. This song has an optimistic hope to offer for Velvet listeners.

\section{Conclusion}

Even though less popular, the Velvets have produced a much deeper and sophisticated form of rock music to be remembered for decades. They also exemplified how artistic rock can be produced for the intelligent crowd who will digest it and realize what music can do when it is not influenced by commercial interests and profit motives. They protested, in their own way, against a greater de-humanization process of the capitalistic world order which their own generation became victims of. But their struggle and protest cannot be identified with that of Dylan or the hippies, since they belonged to a higher intelligent tradition of experiments, which is the motto of reasonbased modernism. They did not go out to be vociferous, since they did not have many things to say. They were dark and withdrawn and continued to 
represent the dark world as it is, without getting bogged down by the bizarre and eclectic arrangements of the decade. This was not typical for many other vociferous rockers at the time. They could exhibit uniqueness in their music, because they were true to their own music as the true expression of their life. They did not have any other life to represent. Existentially speaking, they were the most authentic band which was true to what it said. They represented what they had to represent. They, by no means, humiliated the little crowd they had and were true to the generation they lived with.

The Velvets apparently denied being identified with the contemporary social movement such as San Francisco Hippies, peace movement, left wing or punks, all who have different political agendas. They neither identified themselves with the counter-cultural movement nor with the mainstream. They did not conform to the contemporary middle class values or to the alternative, which again built another hegemonic power. Instead, the Velvets found their own value system which was reclusive and heroin indulgent, a dark and pessimistic rock band which made an extremely artistic, intelligent and innovative music genre to express itself in a cathartic mode through which it was able to produce images of a better world. The non-psychedelic, nihilistic and cynical nature of their music encoded 'signs' to mean that through this infinite darkness, the possibilities of illusionary emergence of symbols of a futuristic better world are not completely obsolete. Through the Velvets' unconscious delirium and nihilism of the excessive use of heroin what one can see is the foggy mirage of a fantasy for a better world.

\section{End Notes}

1 Formed in 1965 Velvet Underground consisted of Lou Reed, John Cale, Sterling Morrison and Maureen Tucker. Nico who joined for the album Velvet Underground and Nico left in 1968. Velvet are known to be one of the most creative rock bands in the histry of rock.

2 http://www.britannica.com/EBchecked/topic/506004/rock\#tab=activ e $\sim$ checked $\% 2$ Citems $\sim$ checked \&title $=$ rock $\% 20--\% 20$ Britannica $\% 20$ Online\%20Encyclopedia

3 See: http://www.collinslanguage.com/results.aspx? context $=3 \&$ reversed $=\mathrm{F}$ alse\&action $=$ define \&homonym $=-1 \&$ text $=$ rock + and + roll

4 See http://en.wikipedia.org/wiki/Rock_music for further information.

5 http://today.msnbc.msn.com/id/4595384/ns/today-entertainment/t/bestrock-bands-ever/\#.UJz2meTqm8o 
6 http://home.att.net/ rarebird9/vus.html

7 The punk subculture is a subculture that is based around punk rock. It emerged from the larger rock ' $n$ ' roll scene in the mid-to-late-1970s in the United Kingdom, the United States and Australia. The punk movement has spread around the globe and developed into a number of different forms. Punk culture encompasses distinct styles of music, ideologies, fashion, visual art, dance, literature, and film. Punk also lays claim to a lifestyle and community. For further information see www. wikipedia.com

8 Chrita Päffgen is a German singer, songwriter, lyrist and a modeller who is well known in the 60s rock culture as the mistress of the Rolling Stone's lead singer Mick Jagger and former member Brain Jones'.

9 Log on to the www.songmeaning.com

10 Ibid

11 Included in Rolling Stones' Exile on the Main Street (1972)

12 See http://www.songmeanings.net/lyric.php?lid=36374 for further details.

\section{References}

Baudrilard, J. (1979). On Seduction: A Selected Essays (trans. Mark Foster), Telios, St. Louis.

Baudrillard, J. (1983). In the Shadow of the Silent Majorities: Or, the End of the Social and Other Essays, Semiotexts, USA.

Bauman, Z. (2004). Wasted Lives: Modernity and Its Outcasts, Polity Press, United Kingdom.

Bauman, Z. (2005). Work, Consumerism and the New Poor, Open University Press, New York.

Burlow, D. H. and Durand, M. V. (2007). Abnormal Psychology, Thomson and Wadsworth, India.

Eagleton, T. (2002). Marxism and Literary Criticism, Rutledge, London.

Foucault, M. (1972). The Order of Things: An Archeology of the Human Sciences, Tavistock, London. 
Garrett, S. (1992). Gender, Routledge, London.

Harvard, J. (2007). The Velvet Underground and Nico, Continuum, New York.

Herbermas, J. (2003). The Future of Human Nature, Polity, London.

Kaufman, W. (1989). Existentialism from Dostoyevsky to Sartre, Meridian Publishing Company, Georgia.

Marcus, G. (1979). Stranded: Rock and Roll for a Desert Island, Random House, London.

Marx, K. and Engels, F. (2000). Communist Manifesto, Penguin, London.

Lacan, J. (2004). Ecrits, Rutledge, London.

Roxon, L. (1969). Rock Encyclopedia, Grosset \& Dunlap, USA.

Sartre, J. P. (2002). Being and Nothingness, Routledge, London.

Scaruffi, P. (2003). History of Rock Music (1951- 2000), iUniverse, New York.

Townshed, D. (1999). Changing the World: Rock ' $n$ 'Roll Culture and Ideology, Verso, London.

Zak, A. (1997). Velvet Underground Companion: Four Decades of Commentary, Schirmer Books, NewYork.

Zizek, S. (2006a). Interrogating the Real, Continuum, London and NY.

Zizek, S. (2006b). Lacan: The Silent Partner, Verso, London.

Zizek, S. (2008). Enjoy Your Symptom, Routledge, London and NY.

\section{Other References}

i. VelvetUnderground, VelvetUndergroundandNico(1967)VerveRecords

ii. Velvet Underground, White Light White Heat (1968) Verve Records

iii. Velvet Underground, Velvet Underground (1969) MGM Records

iv. The Rolling Stones, Exile on the Main Street (1972) Jimmy Miller 
